\title{
Study of Genetic Diversity among Rainfed Barley Genotypes Using ISJ Markers and Morphological Traits
}

\author{
Reza Drikvand $^{1}$, Elham Salahvarzi ${ }^{2}$, Aram Salahvarzi $^{2} \&$ Tahmaseb Hossinpour ${ }^{3}$ \\ ${ }^{1}$ Department of Agronomy and Plant Breeding, Khorramabad branch, Islamic Azad University, Khorramabad, Iran \\ ${ }^{2}$ Department of Plant Production, Khorramabad branch, Islamic Azad University, Khorramabad, Iran \\ ${ }^{3}$ Lorestan Agriculture and Natural Research Center, Iran \\ Correspondence: Reza Drikvand, Department of Agronomy and Plant Breeding, Khorramabad branch, Islamic \\ Azad University, Khorramabad, Iran. Tel: 98-661-4226470. E-mail: drikvand_f@yahoo.com
}

Received: May 28, 2012 Accepted: June 14, 2012 Online Published: July 26, 2012

doi:10.5539/jas.v4n9p137 URL: http://dx.doi.org/10.5539/jas.v4n9p137

\begin{abstract}
Barley ranks below wheat, corn and rice in total world production. Barley is one of the most important crops in Iran. In this study, genetic diversity of 20 rainfed barley genotypes were assessed using morphological traits as well as 20 primers of ISJ semi-random markers. There were significant differences among genotypes for the all traits, indicating high genetic variation among barley germplasm. Based on molecular data, 133 bands were detected and 89 bands were polymorph. The mean number of bands was 6.65 per primer. According to cluster analysis of similarity matrix of molecular and Euclidean distances of morphological data, similarities ranged between $0.42-0.85$ and 1.44-43.22, respectively. Based on molecular data and morphological traits, the highest similarities were belonged to genotypes number 2, $8(0.85)$, and 5, $8(1.44)$ respectively. The results showed that intron-exon splice junction (ISJ) markers and morphological traits rather could distinct two and six-rowed and also hulless and hulled barley genotypes. Distinction of two clusters did not follow the same pattern.
\end{abstract}

Keywords: rainfed barley, morphological traits, genetic diversity, ISJ

\section{Introduction}

Barley (Hordeum vulgare L. subsp. vulgare) is one of the earliest domesticated crop plants, this crop is a high value crop in large parts of arid and drought inflicted regions. In recent years, barley is becoming an important food grain for human consumption due to its nutritional and clinical values (Bathy, 1999; Gill et al., 2002). The development of high-yielding cultivars with improved quality and resistance/tolerance to biotic and abiotic stresses is the main aim of modern barley breeding. The genetic structure and phenotypic expression of a quantitative trait are highly influenced by environmental factors (Breese, 1969). During the last two decades the development of wide range of DNA markers (RFLP, RAPDs, AFLPs, SSRs, STSs and SNPs) and their use in genome analysis has provided unprecedented insight into structural features of the barley genome (Graner et al., 2004). Strelchenko et al. (1999) studied the genetic differentiation of barley from principal cultivation regions of the world using RAPDs, and reported three distinct groups that can be related to the evolutionary directions and geographical distribution of the crop. The first group indicated the westward distribution of barley from west Asia to Europe and New world across Ethiopia and then Mediterranean region. The second group was associated with eastward distribution of the crop and comprised the East Asian and central Asian accessions, and the third group represented the evolution and dissemination of hulless barley in central Asia and Caucasus region. The genetic diversity of $H$. spontaneum in the Australian germplasm collection was investigated using the polymerase chain reaction with random and semi-random primers. The results indicate that the genetic diversity of the wild barleys is broadly correlated with geographic distribution (Weining and Henry, 1995). Vahabi et al. (2008) assessed diversity of 22 populations of plantago ovata using RAPD, ISJ and morphological markers. Cluster analysis based on RAPD showed that a closely association exists among morphological and RAPD dendrograms, while there is no accordance between ISJ-genetic similarity with RAPD and morphological variation. Manjunatha et al. (2007) used morphological and RAPD descriptors of a collection of 70 barley landraces from the higher Himalayan ranges of Uttaranchal state to analyze levels of genetic diversity. A wide range of variation was recorded for various morphological characters in univariate analysis. Clustering based on qualitative traits, however, clearly distinguished naked and hulled forms. RAPD profiles efficiently differentiated 
naked barleys from hulled forms, but could not differentiate between oriental and occidental hulled forms. More diversity was observed in hulled barleys than the naked forms, both for morphological and RAPD markers. Eshghi and Akhundova (2010) investigated genetic diversity among 63 hulless barley accessions originating from ICARDA using agro morphological traits, seed storage protein and RAPD variation. The RAPD-based genetic similarity ranged from 0.22 to 0.81 , with the mean of 0.48 . Cluster analysis based on morphological traits divided genotypes into eight different groups, genotypes with high grain yield were clustered in same group. The average of genetic diversity index for RAPDs and storage proteins were compared and showed that mean of genetic diversity index was less for RAPDs than storage proteins. Hamza et al. (2004) assessed the genetic diversity of 26 Tunisian winter barley cultivars/landraces with $17 \mathrm{SSRs}$, and reported a moderate level of diversity in this sample $(\mathrm{DI}=0.45)$. Moreover, the UPGMA cluster analysis based on SSRs data and morphological data clearly differentiated the local landraces from modern varieties. A good correspondence was found between the clusters based on SSRs and morphological data. Russell et al. (1997) compared the level of polymorphism detected by RFLP, AFLP, SSRs and RAPDs markers, by analyzing 18 barley cultivars. The SSRs detected the highest level of polymorphism compared to other three assays. Some approaches aimed at improving the RAPD analysis, such as the selection of large number of primers and the time and cost of the PCR analysis. PCR based system with semi-random primers targeting the Intron-exon Splice Junction (ISJ), proposed by Weining and Langridge (1991) and developed by Rafalski et al. (2001). The sequences of primers were based on the consensus sequences of the ISJ, 7 and 9 bases in length, common for plants and necessary for effective splicing (Brown, 1986). The additional bases were added at random to extend the length of the primers (Rafalski et al., 1997). The present study was carried out in order to estimate the extent of the genetic diversity in barley advanced lines and cultivars using morphological and ISJ molecular characterization data and comparing them.

\section{Materials and Methods}

\subsection{Plant Materials and Field Experiments}

Twenty rainfed barley genotypes were used in this study obtained from the Lorestan Agriculture and Natural Resources Research Center (Table 1). Genotypes were evaluated using a randomized complete block design with three replications under rainfed conditions. Each plot contained 4 rows with $20 \mathrm{~cm}$ apart and $6 \mathrm{~m}$ in length, and planted at rate of 300 seeds $\mathrm{m}^{-2}$. Ten competitive random plants from the middle rows of the experimental plots were taken for recording the observations on plant height, number of grains spike ${ }^{-1}$, awn length, peduncle length, spike length, 1000-kernel weight and grain yield trait.

Table 1. Name or pedigree and number of row, hulled and hulless of rainfed barley genotypes

\begin{tabular}{llll}
\hline No & Name or pedigree & & \\
\hline 1 & Mahor & 2 row & hulled \\
2 & Viringas/3/h. Sponta.21-3/ Arar 84/w12269/4h & 2 row & hulled \\
3 & DD-21/4/Aliso/C130.9.2// Hb602/3/Nala/So/ ya & 2 row & hulless \\
4 & Atahualpa/Tarida & 2 row & hulled \\
5 & W13159/6/Anca/2469/Toji/3/Shyri/4/Ataco/5/A & 2 row & hulled \\
6 & Izeh Lignee527/Savuson & 6 row & hulled \\
7 & W131180/4/Aliso/C139.902//Hb602/3/Mol/Shy & 2 row & hulled \\
8 & Atahualpa/DD-21 & 2 row & hulled \\
9 & Caimr/F6NB2/Khomes & 6 row & hulled \\
10 & Bkfmaguelone1604/3/Apro//SV.02109/Mari/U/Giza & 6 row & hulled \\
11 & Petunia1/8/Post/Copal/5/Gloria & 6 row & hulless \\
12 & DD-21 & 2 row & hulless \\
13 & BF891M-59//Acc\#116131-Coii\#8901-44-Gizo & 2 row & hulled \\
14 & Atahvalpa/5/Alger/Ceres//SIS/3/ER/APM/4/W12197 & 6 row & hulled \\
15 & Atahulpa/Barque & 2 row & hulled \\
16 & Soufara-o2/RM1508/POR/W12269/41/AML-O2/Arabi/Abiader/APM & 2 row & hulled \\
17 & Alanda/Zafara/Athualpa/5/Lignee527/Chno1//GU/Store/4/RHNO8/3/D & 6 row & hulled \\
& eiiallon/106/PL71/Strain205 & & \\
18 & Alger/Ceres/SIS/3/En/APM/4/WI2197/Mazurka & 2 row & hulled \\
19 & Atahulpa/IPA99 & 6 row & hulled \\
20 & 2Hedarii2/Ndbii2//Mora/5/B1-BAR/Mari & 2 row & hulled \\
\hline
\end{tabular}




\subsection{DNA Isolation and ISJ Method}

For each genotype, a number of seeds were grown in the greenhouse. Young leaves were collected from twoweek old plants. The samples were stored at $-80^{\circ} \mathrm{C}$. DNA was isolated from $100-200 \mathrm{mg}$ of frozen leaves according to the CTAB protocol (Ausubel et al 1999). The DNA concentration of all samples was determined in $0.8 \%$ agarose gels. Primers were used in this study listed in table 2 . The details of the intron-splice-junction primers were previously described by Weining and Langridge (1991). PCR was carried out in a $25 \mu 1$ volume containing 10x PCR buffer, $2 \mu \mathrm{l}$ of genomic DNA template, $0.8 \mu \mathrm{M}$ of each primer (IT or ET), $200 \mu \mathrm{M}$ each of dATP, dCTP, dGTP and dTTP, $50 \mathrm{mM} \mathrm{KC1}, 10 \mathrm{mM}$ Tris-HCl (pH 8.3), $1.5 \mathrm{mM} \mathrm{MgCl}_{2}$, and 1 units of Taq polymerase (Bioron). The PCR was performed in a Thermal Cycler (Bio-Rad Model thermal cycler). The first 7 cycles were at $94^{\circ} \mathrm{C}$ for $1 \mathrm{~min}, 40^{\circ} \mathrm{C} 1.8 \mathrm{~min}$ and $72^{\circ} \mathrm{C} 2 \mathrm{~min}$. This was followed by a further 28 cycles of $94^{\circ} \mathrm{C} 1$ min, $58{ }^{\circ} \mathrm{C} 1.5 \mathrm{~min}$ and $72^{\circ} \mathrm{C} 2 \mathrm{~min}$. PCR products were analyzed on $1.5 \%$ agarose gels and stained with GelRed, visualized under UV and pictured with Gel Documentation.

Table 2. ISJ primers used in the study

\begin{tabular}{llllll}
\hline Primer & \multicolumn{1}{c}{ Sequence $\left(5^{\prime}-3^{\prime}\right)$} & P\%* $^{*}$ & Primer & \multicolumn{1}{c}{ Sequence $\left(5^{\prime}-3{ }^{\prime}\right)$} & P\%* \\
\hline ET 2-18 & ACTTACCTGCTGGCGGA & 42.86 & IT 31-15 & GAAGCCGCAGGTAAG & 100 \\
ET 4-18 & ACTTACCTGCCGCCGAG & 66.67 & IT 34-15 & ACCTACCTGGCCGAG & 60 \\
ET 26-12 & AGCAGGTGGACT & 22.22 & IT 35-15 & CGAAGCCAGGTAAG & 55.56 \\
ET 27-12 & AGCAGGTCCTAG & 100 & IT 10-1 & ACGTCCAGAC & 60 \\
ET 28-12 & AGCAGGTCGAAG & 66.67 & IT 10-2 & ACGTCCAGGT & 66.67 \\
ET 29-12 & AGCAGGTCGTGA & 33.33 & IT 10-3 & ACGTCCAGCA & 77.78 \\
ET 30-12 & AGCAGGTGGTAC & 83.33 & IT 10-4 & ACGTCCACCA & 75 \\
ET 35-15 & ACTTACCTGCCGCAG & 75 & IT 10-5 & ACGTCCAGAG & 85.71 \\
ET 31-15 & ACTTACCTGGGCCAG & 100 & IT 10-6 & ACGTCCATCC & 80 \\
ET 10-18 & ACTTACCTGAGGGCGAC & 100 & IT 36-15 & ACCTACCTGGGGCTC & 75 \\
\hline
\end{tabular}

*: Polymorphism percentage

\subsection{Statistical Analysis}

Morphological data were analyzed using SAS (SAS Institute, 2002), and means were compared by Duncan's multiple range test at 0.05 probability level. Cluster and principal component analysis were also employed using SPSS (version 11.5) software. The ISJ markers were scored, depending on the presence (1) or absence (0) of the bands. It was also used in obtaining other results as well as similarity coefficient matrix of Jaccard (Jaccard, 1908). Based on similarity matrix, a dendrogram showing the genetic relationships between genotypes was constructed using the un-weighted pair group method with arithmetic average (UPGMA) through the software NTSYS-pc program (Rohlf, 1992).

\section{Results and Discussion}

\subsection{Morphological Traits}

Significant differences were observed among wheat genotypes for all morphological traits (Table 3). These results indicate the presence of high genetic variation among genotypes. Comparison means of traits are shown in Table 4. As it is shown, hulless barley genotypes have lower grain yield than hulled genotypes. Genotypes 4 and 16 with 3.70 and 3.51 grain yield $\left(\mathrm{t} \mathrm{ha}^{-1}\right)$ scored the highest yield among genotypes under study. The hulless barleys were generally poor yielding than hulled barley; yields of current hulless barley are generally 10 to 20 percent lower than those of hulled barley genotypes, (Manjunatha et al., 2007). Since the hulless barley easily lose their husk cover of caryopses, its grain yield was less than hulled barley. Other trait means are shown in Table 3. Principal component analysis was performed for all traits under study (Table 5). The first two components could justify more than $62.46 \%$ of the whole variance in the original data. The first component could justify the most amount of variance among genotypes (37.28\%). Rotate component matrix showed that awn length, plant height, and grain yield were in the first group (component1) and number of grains spike ${ }^{-1}$, peduncle length, spike length and 1000-kernel weight were in the second group (component2). It can be 
concluded that the traits of each group are correlated. According to similarity matrix of Euclidean distances, similarities ranged between 1.44-43.22, highest similarities were belonged to genotypes numbers 5 and 8 (1.44), these are two-rowed and have the most similarity especially in grain yield (Table 4). The least similarity belonged to genotypes 3 (hulless) and 16 (hulled), these genotypes are also two-rowed. Cluster analysis based on morphologic traits was carried out using Ward method (Figure 1) if the cutting is done on the distance 16; genotypes are divided into five major groups. Twelve genotypes were grouped in cluster-I, which are two-rowed, except No, 17. These genotypes had high grain yield. Cluster-II comprised two genotypes, which were low grain yield. Cluster-III contained two six-rowed genotypes. Two hulless barley fall in cluster-IV and one of them falls in cluster-V. It can be concluded that cluster analysis based on morphological traits could rather distinct genotypes. Although morphological traits are influenced by environment, in some cases they can be used for plant genetic diversity investigation.

Table 3. ANOVAs of morphological traits in rainfed barley genotypes

\begin{tabular}{lllllllll}
\hline S.O.V. & df & $\begin{array}{c}\text { Plant } \\
\text { height }\end{array}$ & $\begin{array}{c}\text { Number of } \\
\text { grains spike }^{-1}\end{array}$ & $\begin{array}{c}\text { Awn } \\
\text { length }\end{array}$ & $\begin{array}{c}\text { Peduncle } \\
\text { length }\end{array}$ & $\begin{array}{c}\text { Spike } \\
\text { length }\end{array}$ & $\begin{array}{c}1000 \text {-kernel } \\
\text { weight }\end{array}$ & $\begin{array}{c}\text { Grain } \\
\text { yield }\end{array}$ \\
\hline Replication & 2 & 166.86 & 3738.81 & 8.22 & 46.50 & 1.59 & 113.21 & 9.99 \\
Genotype & 19 & $253^{* *}$ & $8455.09^{* *}$ & $10.43^{* *}$ & $26.84^{* *}$ & $2.20^{* *}$ & $39.30^{* *}$ & $1.06^{* *}$ \\
Error & 38 & 53.59 & 1685.09 & 1.62 & 7.97 & 0.30 & 5.81 & 0.42 \\
CV\% & & 12.37 & 24.93 & 9.49 & 22.11 & 8.14 & 5.16 & 25 \\
\hline
\end{tabular}

** :significant at 0.01 probability level.

Table 4. Mean comparison of morphological traits in rainfed barley genotypes

\begin{tabular}{|c|c|c|c|c|c|c|c|}
\hline No & $\begin{array}{l}\text { Plant height } \\
\text { (cm) }\end{array}$ & $\begin{array}{l}\text { Number of } \\
\text { grain spike }^{-1}\end{array}$ & $\begin{array}{l}\text { Awn length } \\
(\mathrm{cm})\end{array}$ & $\begin{array}{c}\text { Peduncle } \\
\text { length }(\mathrm{cm})\end{array}$ & $\begin{array}{c}\text { Spike } \\
\text { length }(\mathrm{cm})\end{array}$ & $\begin{array}{l}\text { 1000-kernel } \\
\text { weight (g) }\end{array}$ & $\begin{array}{c}\text { Grain yield } \\
\left(\mathrm{kg} \mathrm{h}^{-1}\right)\end{array}$ \\
\hline 1 & $42.33 \mathrm{~h}$ & $135.33 \mathrm{~cd}$ & 14.51 bcde & $9.23 \mathrm{~cd}$ & $6.13 \mathrm{defg}$ & $46.33 \mathrm{bcd}$ & $3.05 \mathrm{abcd}$ \\
\hline 2 & $50.40 \mathrm{fgh}$ & $104.67 \mathrm{~d}$ & $10.91 \mathrm{~h}$ & $7.03 \mathrm{~d}$ & $7.01 \mathrm{cde}$ & $47.33 \mathrm{abcd}$ & $2.28 \mathrm{bcde}$ \\
\hline 3 & $66.50 \mathrm{abcd}$ & $149.33 \mathrm{~cd}$ & $15.51 \mathrm{bcd}$ & $6.81 \mathrm{~d}$ & $9.05 \mathrm{a}$ & $47.66 \mathrm{abcd}$ & $1.8 \mathrm{de}$ \\
\hline 4 & 63.06abcdef & $140.67 \mathrm{~cd}$ & $12.71 \mathrm{efgh}$ & $10.65 \mathrm{bcd}$ & $6.78 \mathrm{def}$ & $49 a b c$ & $3.7 \mathrm{a}$ \\
\hline 5 & 56.16 cdfghe & $108 \mathrm{~d}$ & $11.65 \mathrm{gh}$ & $8.81 \mathrm{~cd}$ & $6.58 \mathrm{def}$ & $51.66 \mathrm{a}$ & 2.88 abcde \\
\hline 6 & $50.56 \mathrm{fgh}$ & $194.67 \mathrm{bc}$ & $118.28 \mathrm{fgh}$ & $15.51 \mathrm{ab}$ & $5.40 \mathrm{~g}$ & $47.33 \mathrm{abcd}$ & $3.41 \mathrm{abc}$ \\
\hline 7 & $61.16 \mathrm{bcdef}$ & $134 \mathrm{~cd}$ & $14.18 \mathrm{bcdef}$ & $13.55 \mathrm{abc}$ & $7.98 \mathrm{bc}$ & $50.66 \mathrm{ab}$ & 2.43 abcde \\
\hline 8 & $52.13 \mathrm{efgh}$ & $128.67 \mathrm{~cd}$ & $12.63 \mathrm{efgh}$ & $11.16 \mathrm{bcd}$ & $6.46 \mathrm{def}$ & $51 \mathrm{ab}$ & 2.88 abcde \\
\hline 9 & 57.16 bcdeg & $245 \mathrm{ab}$ & $11.61 \mathrm{gh}$ & $12.73 a b c$ & $5.78 \mathrm{bg}$ & $51.66 \mathrm{a}$ & $2.31 \mathrm{bcde}$ \\
\hline 10 & $67.76 \mathrm{abcd}$ & $253 \mathrm{ab}$ & 14 bcdefg & $15.88 \mathrm{ab}$ & $6.28 \mathrm{defg}$ & $38.33 \mathrm{f}$ & $2.59 \mathrm{abcd}$ \\
\hline 11 & $70.83 \mathrm{ab}$ & $287.33 \mathrm{a}$ & $15.80 \mathrm{bc}$ & $13.35 \mathrm{abc}$ & $6.99 \mathrm{~cd}$ & $43.33 \mathrm{de}$ & $1.96 \mathrm{de}$ \\
\hline 12 & $68.96 \mathrm{abc}$ & $248.33 \mathrm{ab}$ & $18.36 \mathrm{a}$ & $15.38 \mathrm{ab}$ & $8.28 \mathrm{ab}$ & $43.66 \mathrm{de}$ & $1.88 \mathrm{de}$ \\
\hline 13 & $61.96 \mathrm{bcdef}$ & $162.67 \mathrm{dc}$ & 13.28 defgh & $15.28 \mathrm{ab}$ & $5.93 \mathrm{efg}$ & $47.66 \mathrm{abcd}$ & 2.46 abcde \\
\hline 14 & $51.73 \mathrm{fgh}$ & $128.33 \mathrm{a}$ & $15.91 \mathrm{~b}$ & $15.93 \mathrm{ab}$ & $7.19 \mathrm{~cd}$ & $49.33 \mathrm{abc}$ & 2.15 cde \\
\hline 15 & $76.70 \mathrm{a}$ & $145 \mathrm{~cd}$ & $11.71 \mathrm{fgh}$ & $17.01 \mathrm{a}$ & $6.65 \mathrm{def}$ & $49.66 \mathrm{abc}$ & 2.81 abcde \\
\hline 16 & $50.46 \mathrm{fgh}$ & $138.33 \mathrm{~cd}$ & 12.70 efgh & $148 \mathrm{ab}$ & $6.43 \mathrm{defg}$ & $43.66 \mathrm{de}$ & $3.51 \mathrm{ab}$ \\
\hline 17 & 54.20 defgh & $129 \mathrm{~cd}$ & $12.45 \mathrm{efgh}$ & $13.98 \mathrm{abc}$ & $6.09 \mathrm{ed}$ & $47.66 \mathrm{abcd}$ & 2.76 abcde \\
\hline 18 & $47.46 \mathrm{gh}$ & $207 \mathrm{abc}$ & 13.15 defgh & $12.6 \mathrm{abc}$ & $6.83 \mathrm{def}$ & $45.33 \mathrm{cde}$ & $3.08 \mathrm{abcd}$ \\
\hline 19 & $68.33 \mathrm{abcd}$ & $134 \mathrm{~cd}$ & 13.43 cdefg & $11.94 \mathrm{abcd}$ & 7.01 cde & $41 \mathrm{ed}$ & $1.62 \mathrm{e}$ \\
\hline 20 & 65.06 abcde & $128 \mathrm{~cd}$ & $11.98 \mathrm{fgh}$ & $13.68 \mathrm{abc}$ & $6.31 \mathrm{defg}$ & $44.33 \mathrm{de}$ & $2.03 \mathrm{de}$ \\
\hline
\end{tabular}

Means followed by same letters in each column are not significantly different at 0.05 levels of probability. 
Table 5. The principal component analysis for morphological traits

\begin{tabular}{cccccccccc}
\hline Component & $\begin{array}{c}\text { Eigen } \\
\text { value }\end{array}$ & $\begin{array}{c}\text { Cumulative } \\
\text { percentage }\end{array}$ & $\begin{array}{c}\text { Plant } \\
\text { height }\end{array}$ & $\begin{array}{c}\text { Number of } \\
\text { grains } \\
\text { spike }\end{array}$ & $\begin{array}{c}\text { Awn } \\
\text { length }\end{array}$ & $\begin{array}{c}\text { Peduncle } \\
\text { length }\end{array}$ & $\begin{array}{c}\text { Spike } \\
\text { length }\end{array}$ & $\begin{array}{c}1000- \\
\text { kernel } \\
\text { weight }\end{array}$ & $\begin{array}{c}\text { Grain } \\
\text { yield }\end{array}$ \\
\hline 1 & 2.61 & 37.28 & 0.69 & 0.56 & 0.80 & 0.26 & 0.60 & -0.51 & -0.68 \\
2 & 1.76 & 62.46 & 0.08 & 0.57 & -0.12 & 0.76 & -0.68 & -0.42 & 0.41 \\
\hline
\end{tabular}

\subsection{ISJ Data Analyses}

In the present study, 20 ISJ primers belonged to two groups of Intron Targeting (IT) and Exon Targeting (ET) that showed a high level of polymorphism and a high number of clearly amplified bands (Figure 2). Primers generated 133 bands ( 89 polymorphic bands) that their sizes were varied from 100-1500 bp, the mean number of bands was 6.8 per primer. Rafalski et al. (2002) used semi-random primers in rye genotypes and reported that average number of bands per primer is 8.9. The highest number of polymorph band was obtained with primers IT10-3 and IT10-1, while the lowest number was obtained with primer ET26-12. Generally, IT primers in comparison with the ET primers generated polymorphic fragments with higher resolution; these findings are in accordance with the results of Vahabi et al. (2008) in Plantago. Polymorphism percentage ranged from 22.22 to $100 \%$ (Table 2). ISJ data were utilized to calculate the genetic similarity matrix using Jaccard similarity coefficient and UPGMA method. Similarities ranged between $0.42-0.85$, the lowest genetic similarity (42\%) was found between genotypes numbers 12 (hulless) and 18 (hulled), while the highest (85\%) was observed between genotypes number 2 and 8 , both genotypes are hulled and two-rowed barley. Genetic similarities among the genotypes are presented as a dendrogram (Figure 3). If the cutting is done on the $70 \%$ similarity coefficient, genotypes will divided into five major groups. Cluster-I comprised two hulled barleys, cluster-II contained maximum number (14) of genotypes that were mainly two-rowed and hulled barleys.

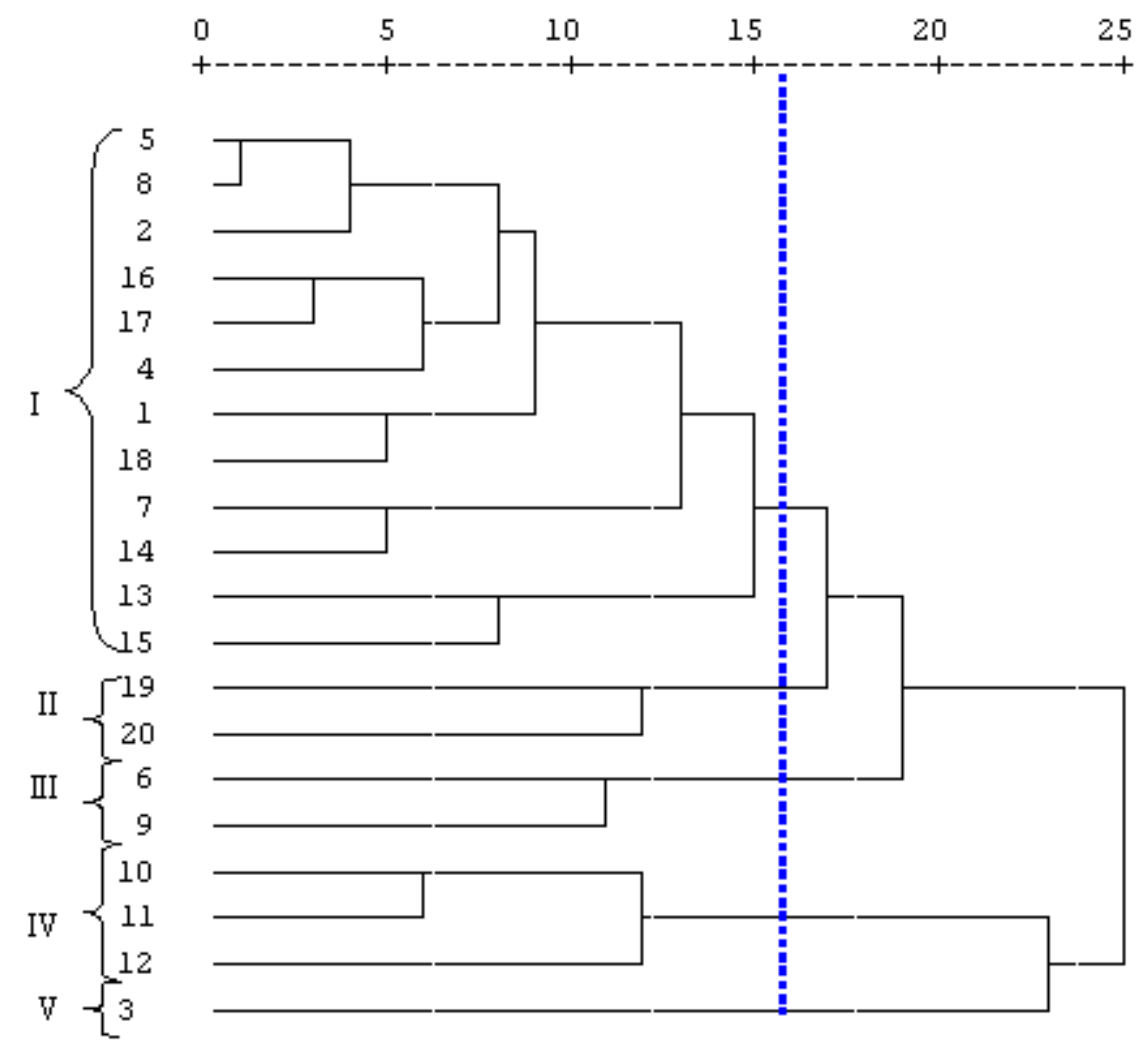

Figure 1. Dendrogram of rainfed barley genotypes using ward method based on Euclidian distance for morphological traits 


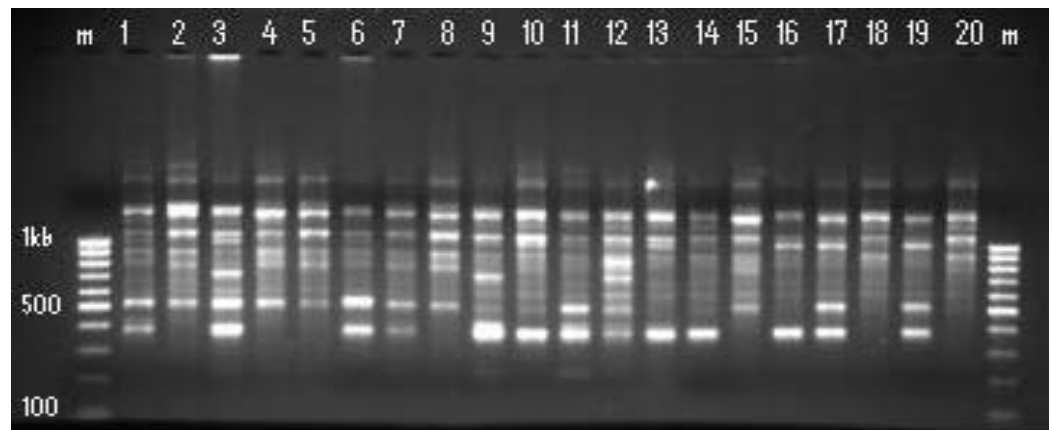

Figure 2. Banding pattern of rainfed barley genotypes using IT10-1primer in agaros gel

Only one genotype grouped in each of the cluster-III and IV that were two-rowed and hulled barley. Cluster-V comprised two hulless and two-rowed barleys. Thus, the marker can well separate hulless and two-rowed genotypes, also hulled and two-rowed genotypes groups in one cluster. So ISJ markers almost succeed in separation of genotypes.

\subsection{Comparison between Morphological Traits and ISJ Polymorphisms}

The morphological and ISJ data gives two dendograms with five groups that were not completely corresponding; however there were some concordances between them. Two dendrograms distinct hulless and two-rowed barley efficiently (No 3 and 12) similarity in both denrograms majority of two-rowed barley were in one group. Although morphological traits are strongly associated with environmental variation and the morphological similarities observed may be due to the under laying genetic differences, the present study showed that some morphological similarities may have molecular basis. Manjunatha et al (2007) in barley found that clustering based on qualitative traits and RAPD marker, clearly distinguished naked and hulled forms. Eshghi and Akhundova (2010) in hulless barley reported that there is no correlation between RAPD marker and morphological traits. Hamza et al. (2004) showed that the correlation between SSR markers and morphological traits was highly significant, and the correspondence between the clustering based on DNA markers and morphological data was relatively good. In some cases, two clusters do not match. For example, both markers could not well separated six-rowed genotypes, although in this case, cluster analysis based on morphological traits had better result, as genotypes number 3,11 and 12 were closely related in the morphological based analysis, in ISJ analysis only genotypes number 3 and 12 were related. One reason probably is that genotypes number 3 and 12 are two-rowed, while genotypes number 11 is six-rowed. Semagn (2002) suggested two reasons for low correlation between DNA markers and morphological data: (1) DNA markers cover a larger proportion of the genome, including coding and noncoding regions, than the morphological markers. (2) DNA markers are less subjected to artificial selection compared with morphological markers. Martinez et al. (2003) and Salem et al. (2008) believed that the correspondence between different methods might be improved by analyzing more morphological characters, and DNA markers. The present study showed a large amount of genetic variation which exists between rainfed barley genotypes can be used efficiently to select parent for improved genotypes. Genotypes that have the greatest genetic distance can be used as the parent in breeding programs.

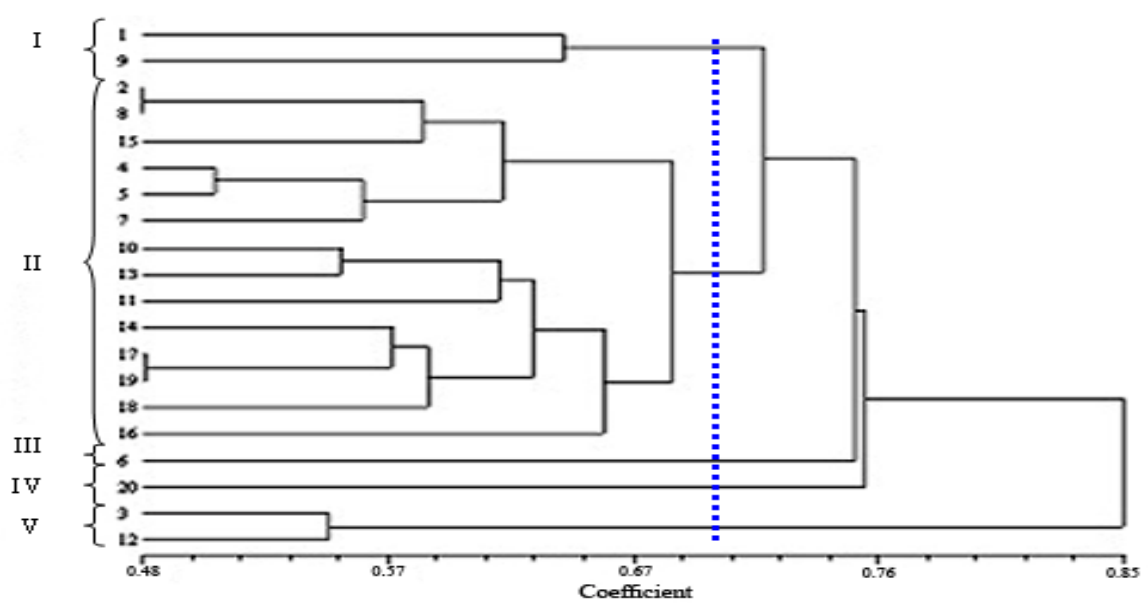

Figure 3. Dendrogram of rainfed barley genotypes using UPGMA method based on Jaccard's coefficient for ISJ data 


\section{Acknowledgements}

The authors are grateful to A. Mirazadi for many helpful comments and suggestions. This work was supported by grants from the Research Council of the Islamic Azad University, Khorramabad Branch, Iran.

\section{References}

Ausubel, F. M., Brent, R., Kingston, R. E., Moore, D. D., Seidman, J. G., Smith, J. A., \& Struhl, K. (1999). Short Protocols in Molecular Biology: A Compendium of Methods from Current Protocols in Molecular Biology, 4th edn. Wiley, New York. http://www.currentprotocols.com/protocol

Barret, B. A., \& Kidwell, K. K. (1998). AFLP based genetic diversity assessment among wheat cultivars from Pacific Northwest. Crop Sci., 38, 1261-71. http://dx.doi.org/10.2135/cropsci1998.0011183X003800050025x

Bhatty, R. S. (1999). The potential of hulless barley. Cereal Chemistry Journal, 76, 589-599. http://dx.doi.org/10.1094/CCHEM.1999.76.5.589

Breese, E. D., (1969). The measurement and significant of genotype-environment interaction in grasses. Heredity, 21, 27-47. http://dx.doi.org/10.1038/hdy.1969.3

Brown, J. W. (1986). A catalogue of splice junction and putative branch point sequences from plant introns. Nucleic Acids Research, 14, 9549-9559. http://dx.doi.org/10.1093/nar/14.24.9549

Eshghi, R., \& Akhundova, E. (2010). Genetic diversity in hulless barley based on agro morphological traits and RAPD markers and comparison with storage protein analysis. African Journal of Agricultural Research, 5, 97-107. Available online at http://www.academicjournals.org/AJAR

Gill, S., Vasanthan, T., Ooraikul, B., \& Rossnagel, B. (2002). Wheat bread quality as influenced by the substitution of waxy and regular barley flours in their native and extruded forms. Journal of Cereal Science, 36, 219-237. http://dx.doi.org/10.1006/jcrs.2001.0458

Graner, A., Kota, R., Perovic, D., Potokina, E., Prasad, M., Scholz, U., Stein, N., Thiel, T., Varshney, R. K., \& Zhang, H. (2004). Molecular mapping: shifting from the structural to the functional level. Proceedings of the 9th International Barley Genetics Symposium. Brno, Czech Republic pp 49-57

Hamza, S., Hamida, W. B., Rebai, A., \& Harrabi, M. (2004). SSR-based genetic diversity assessment among Tunisian winter barley and relationship with morphological traits. Euphytica, 135, 107-118. http://dx.doi.org/10.1023/B:EUPH.0000009547.65808.bf

Jaccard, P. (1908). Nouvelles recherches sur la distribution florale. Bulletin Society Vaud Science National, 44, $223-270$

Manjunatha, T., Bisht., I. S., Bhat., K.V., \& Singh, B. P. (2007). Genetic diversity in barley (Hordeum vulgar L. ssp. vulgar) landraces from Uttaranchal Himalaya of India. Genetic Resources and Crop Evolution, 54, 55-65. http://dx.doi.org/10.1007/s10722-005-1884-6

Maric, S., Bolaric, S., Martincic, J., Pejic, I., \& Kozumplik, V. (2004). Genetic diversity of hexaploid wheat cultivars estimated by RAPD markers, morphological traits and coefficients of parentage. Plant Breeding, 123, 366-369. http://dx.doi.org/10.1111/j.1439-0523.2004.00956.x

Martinez, L., Cavagnaro, P., Masuelli, R., \& Rodriguez, J. (2003). Evaluation of diversity among Argentina grapevine (Vitis vinifera L.) varieties using morphological data and AFLP markers. Electronic Journal of Biotechnology, 6, 241-250. http://dx.doi.org/10.2225/vol6-issue3-fulltext-11

Rafalski, A., Gizinska, M., \& Wisniewska, I. (1997). PCR-based system for evaluation of relationships among maize inbred genetic biotechnology and breeding maize and sorghum. $1^{\text {st }}$ End. Royal Society of Chemistry, Cambridge, UK. pp. 106-111.

Rafalski, A., Wiśniewska, I., Adamczyk, J., Gaweł, M., \& Królikowski, Z. (2001) Molecular analysis of genetic diversity among maize inbred lines (In Polish, English abstract). Biul. IHAR., 217, 127-137.

Rafalski, A., Madej, L., Wisniewska, I., \& Gawel, M. (2002). The genetic diversity of component of rye hybrids. Cellular and Molecular Biology Letters, 7, 471-475.

Rohlf, F. J. (1992). NTSYS-pc: numerical taxonomy and multivariate analysis system. Exeter Software. New York. Available: http:/www.exetersoftware.com

Russell, J. R., Fuller, J. D., Macaulay, M., Hatz, B. G., Jahoor, A., Powell, W., \& Waugh, R. (1997). Direct comparison of levels of genetic variation among barley accessions detected by RFLPs, AFLPs, SSRs and RAPDs. Theoretical and Applied Genetics, 95, 714-722. http://dx.doi.org/10.1007/s001220050617 
Salem, K. F. M., El-Zanaty, A. M., \& Esmail, R. M. (2008). Assessing wheat (Triticum aestivum L.) genetic diversity using morphological characters and micosatallite markers. World Journal of Agriculture of Science, 4(5), 538-544. www.idosi.org/wjas/wjas4

SAS Institute. (2002). SAS user's guide: Statistics version 9 for windows. SAS Institute., Carry, NC.

Semagn. K. (2002). Genetic relationships among ten endod types as revealed by a combination of morphological, RAPD and AFLP markers. Hereditas, 137, 149-156. http://dx.doi.org/10.1034/j.1601-5223.2002.01600.x. PMid:12627842

Strelchenko, P., Kovalyova, O., \& Okuno, K. (1999) Genetic differentiation and distribution of barley germplasm based on RAPD markers. Genetic Resources and Crop Evolution, 46, 193-205. http://dx.doi.org/10.1023/A:1008654612941

Weining, S., \& Langridge, P. (1991). Identification and mapping of polymorphism in cereals based on the polymerase chain reaction. Theoretical and Applied Genetics, 82, 209-216. http://dx.doi.org/10.1007/BF00226215

Weining, S., \& Henry, R. J. (1995). Molecular analysis of the DNA polymorphism of wild barley (Hordeum spontaneum) germplasm using the polymerase chain reaction. Genetic Resources and Crop Evolution, 42, 273-281. http://dx.doi.org/10.1007/BF02431262

Vahabi, A. A., Lotfi, A., Solouki, A., \& Bahrami, S. (2008). Molecular and morphological markers for the evaluation of diversity between Plantago ovata in Iran. Biotechnology, 7(4), 702-708. http://dx.doi.org/10.3923/biotech.2008.702.709 